\title{
Esensi Perbedaan Metode Kualitatif Dan Kuantitatif
}

\author{
M. Firmansyah"1, M a s r u n ${ }^{2}$, I Dewa Ketut Yudha $S^{3}$ \\ Fakultas Ekonomi dan Bisnis Universitas Mataram \\ *Corresponding Email: firmansyah.feb@unram.ac.id \\ Email: ${ }^{2}$ masrun.feunram@yahoo.com, ${ }^{3}$ Dewayudha2016@gmail.com
}

\begin{tabular}{ll}
\hline \multicolumn{1}{c}{ Info Artikel } & \multicolumn{1}{c}{ ABSTRAK } \\
\hline Kata Kunci: & Penelitian kualitatif saat ini telah mendapat tempat dalam kajian- \\
pendekatan kuantitatif, & kajian ilmiah di lingkup fakultas ekonomi dan bisnis. Telah banyak \\
pendekatan kualitatif, & tugas akhir mahasiswa berupa skripsi, tesis dan disertasi yang \\
penomoran dan intepretif & $\begin{array}{l}\text { menggunakan metode penelitian kualitatif. Namun dalam } \\
\text { pelaksanaannya perbedaan antara kuantitatif dan kualitatif masih } \\
\text { samar-samar di kalangan mahasiswa dan juga dosen yang terbiasa } \\
\text { dengan metode kuantitatif. Sehingga masih dibutuhkan penjelasan } \\
\text { perbedaan kedua metode tersebut. Artikel ini menjelaskan esensi } \\
\text { perbedaan pendekatan kuantitatif dan kualitatif. Artikel ini } \\
\text { menggunakan analisis kepustakaan. }\end{array}$ \\
&
\end{tabular}

\section{PENDAHULUAN}

Di awal abad ke-20 beberapa filosof dan peneliti menyuarakan untuk melihat kembali metode penelitian yang selama ini mewarnai kajian ilmiah. Mereka mengkritik cara pandang, pendekatan riset berhaluan positivis (baca: kuantitatif) yang selama ini digunakan. Pendekatan positivis dianggap belum melayani pengetahuan dengan baik (Baden dan Major, 2010: 1).

Walau-pun ditemukan beberapa keterbatasan, orientasi kuantitatif masih lebih sering diberi rasa hormat. Masyarakat umum menganggap ilmu penomoran lebih disukai (Berg, 2001: 2) dari memaknai (meaning) dan menggali fenomena mendalam. Ilmu ekonomi misalnya oleh sebagian kalangan lebih dianggap sebagai tecnical dicipline dari pada social dicipline, karena cenderung matematis dengan berbagai teknis perhitungan rumit. Padahal, ekonomi merupakan bagian dari kompleksitas fenomena sosial, yang oleh ChamleeWright (2010) samakan dengan puzzle beribu teka-teki.

Alternatif yang diambil guna memenuhi keinginan menjawab kompleksitas fenomena itu, riset bidang ekonomi dan bisnis di beberapa perguruan tinggi mulai mencoba memperkenalkan metode pemaknaan mendalam (indept research) atau kualitatif. Di Indonesia, beberapa perguruan tinggi ternama banyak menghasilkan studi kualitatif sebagai tugas akhir mahasiswa ekonomi dan bisnis, khususnya jenjang S-2 dan S3. Mahasiswa semakin variatif memilih paradigma meneliti, tidak lagi terpaku hanya dengan pendekatan kuantitatif. 
Dalam pelaksanaan antara pendekatan kuantitatif dan kualitatif masih samar-samar. Khususnya di kalangan mahasiswa dan dosen yang terbiasa dengan pendekatan kuantitatif. Artikel ini menjelaskan esensi perbedaan antara pendekatan kuantitatif dengan kualitatif.

\section{METODE PENELTIAN}

Jenis penelitian ini adalah studi kepustakaan. Studi kepustakaan adalah teknik analisis dengan menelaah literatur, catatan, laporan terkait dengan permasalahan yang ingin dipecahkan. Penelitian dilakukan dengan menggali sumber yang menjelaskan perbedaan metode kuantitatif dengan kualitatif atau penjelasan di antara ke duanya secara parsial.

\section{PEMBAHASAN}

Mendalami perbedaan metode kualitatif dan kuantitatif salah satunya dengan memahami studi pengetahuan (knowladge) yang disebut sebagai epistemologi. Mengacu pada falsafah epistemologi asumsi dari pendekatan kualitatif dan kuantitatif dalam ranah penelitian memiliki perbedaan yang radikal (Vanderstoep dan Johnston, 2009: 165). Bagi Bryman perlakuan (treatmen) kedua pendekatan ini berlaku mutually antagonistic (Bryman, 2004: 93). Ada beberapa karakteristik dasar sebagai pembeda yaitu: Kerangka konseptual, faktor penjelas, konsep rasionalitas dan keberadaan teori.

Rancang bangun kerangka konseptual penelitian kualitatif terbentuk di lapangan, artinya konseptual terbentuk setelah melakukan studi lapangan awal. Sedangkan penelitian kuantitatif dirancang di atas meja kerja ketika menyusun proposal penelitian. Faktor penjelas penelitian kualitatif juga ditentukan di lapangan yang disebut sebagai tema-tema penelitian. Sedangkan, faktor penjelas dalam penelitian kuantitatif yang disebut variabel atau parameter ditentukan terlebih dahulu bersamaan dengan hipotesis yang akan diuji.

Dalam perspektif lain, konsep rasionalitas yang merupakan gambaran penentu perilaku terdapat perbedaan mendasar. Kuantitatif mengakomodir nilai-nilai positivis tentu menyandarkan sifat rasionalitas pada konsep homo economicus di mana yang terbaik adalah yang terbesar, terbanyak. Manusia cendrung rasional dan tidak didasarkan oleh nilai-nilai lokal (local wisdom). Bertolak belakang dengan itu, penelitian kualitatif yang menganut nilai normatif, dengan menganggap perilaku rasional juga dipengaruhi oleh nilai-nilai yang oleh Thortstain Veblen (tokoh ekonomi kelembagaan) sebut sebagai habits dan routins (kebiasaan dan rutinitas). Tokoh ekonomi kelembagaan baru (new institutional economics) Herbert Simon menjembatani dua pola perbedaan estrim antara pemikir ekonomi neo-klasik (positivis) dan kelembagaan lama (Veblen) dengan membangun kerangka pikir rasionalitas terbelenggu (bounded rationality). Di mana menurut Simon rasionalitas perilaku manusia terbelenggu, terbatas oleh a simentri informasi dan struktur lingkungan.

Terkait eksistensi teori dalam penelitian juga ada perbedaan. Keberadaan teori dalam penelitian kuantitatif adalah mutlak diperlukan. Teori merupakan petunjuk utama penelitian, teori merupakan penentu arah penelitian bahkan sebagai acuan hipotesis yang akan diuji. Sehingga dari awal perlu ada yang namanya grand theory yang menjadi payung setiap penelitian. Sedangkan penelitian kualitatif teori hanya diperlukan untuk membantu peneliti menyusun pertanyaan atau membantu peneliti di lapangan. Jadi teori dalam penelitian kualitatif tidaklah secara baku ditentukan dari awal, namun teori 
bisa juga dicari, dilengkapi saat di lapangan sehingga dapat dilakukan perbandingan antara teori yang ada dengan fenomena yang ada di lapangan. Metode kuantitatif menganggap ilmu ditandai dengan penelitian empiris, fenomena dapat direduksi dengan indikator empiris yang mewakili kebenaran, sementara itu dari aspek ontologis (realitas) hanya satu kebenaran di mana realitas objektif pada manusia adalah independent (Sale, Lohfeld dan Brazil, 2002). Lebih jauh Sale, Lohfeld dan Brazil (2002) mengatakan secara epistemologis penyidik dan yang diselidiki adalah entitas yang independent, sehingga peneliti hanya mampu mempelajari fenomena tanpa mempengaruhi atau dipengaruhi oleh fenomena itu.

Dalam konteks jumlah informan atau responden antara kualitatif dan kuantitatif menunjukkan perbedaan yang ekstrem. Metode kuantitatif walaupun menggunakan metode sampling dari populasi, tetap membutuhkan banyak responden, sedangkan kualitatif secara khusus hanya pada beberapa responden/ informan dalam kebutuhan wawancara mendalam atau indepth intervew (Debrofoni dan Fuentes, 2008). Mengingat kualitatif merupakan studi pemaknaan (intepretif) maka tergantung sungguh dari intuisi dan pemahaman yang berbeda-beda dari setiap individu. Oleh karenanya peneliti diharuskan terjun sendiri secara langsung dengan tidak menggunakan enumerator atau asisten, karena dikhawatirkan melahirkan interpretasi makna fenomena yang berbeda antara peneliti dengan asistennya. Membedakan antara pendekatan kuantitatif dan kualitatif, selanjutnya Dabbs dalam Berg (2001:2) menunjukkan bahwa gagasan kualitas adalah penting untuk hal sifat. Kualitas merujuk pada konteks apa, bagaimana, kapan, dan di mana dari esensi "sesuatu". Sekaligus memasukkan unsur suasana "sesuatu" itu.
Sehingga penelitian kualitatif akan mengacu pada: konsep dari makna, definisi, karakteristik, metafora, simbol dan hal lain berkaitan dengan deskripsi.

Sebaliknya, penelitian kuantitatif mengacu pada jumlah dan ukuran. Dalam memaknai hasil, penelitian kuantitatif mencoba mengurai keluasan hasil studi dan menggeneralisasi sebagai kebenaran atau fakta empiris secara umum, sedangkan penelitian kualitatif mengkaji ke dalaman fakta atau kejadian, sehingga bersifat lokal dan tidak dalam rangka generalisasi temuan empiris sebagai kejadian umum.

Metode kuantitatif mengasumsikan pengetahuan adalah "out there" maka pengetahuan itu untuk ditemukan, ada realitas yang dapat diketahui secara fisik oleh peneliti yang terlatih. Kualitatif mengasumsikan pengetahuan sebagai hasil konstruksi pemahaman, bersumber dari komunikasi dan interaksi, sehingga pengetahuan bukan "out there" tetapi di dalam persepsi dan intepretasi dari individu. Pendek kata, pengetahuan dikonstruksikan atau dikreasikan oleh masyarakat, sehingga disebut social construction of reality (Vainderstoep dan Johnston, 2009: 165-166).

Pandangan di atas menyiratkan, penelitian kualitatif meyakini bahwa di balik fenomena ada "noumena", di balik perilaku ada pemahaman, proses memilih dan memutuskan terejawantah dalam bentuk tindakan, di mana tindakan merupakan buah dari pikiran dan pemahaman tersebut. Di balik keputusan, ada outcomes yang diharapkan untuk dicapai oleh individu sehingga keputusan harus dipilih dan diharapkan memaksimalkan utilitas baginya. Oleh karena itu, dalam memaknai keputusan dan perilaku yang berkembang perlu peran intuisi di situ. Sebagai contoh kata "iya" atau "tidak" dari seorang informan belum tentu merupakan jawaban yang sesungguhnya dari informan. Artinya jawaban "iya" bisa juga dimaknai "tidak". 
Jawaban "iya" dengan bahasa tubuh, raut muka yang tidak menunjukkan arah yang sama (mendukung) bisa jadi berarti "tidak". Artinya, di bibirnya berkata "iya" namun dalam hati yang tergambar dari bahasa tubuh sebenarnya menganggap "tidak". Bahkan ketika seseorang yang diteliti tidak menjawab sekalipun dapat berarti sebuah sikap, memiliki makna yang merupakan jawaban dari fenomena kualitatif itu sendiri. Fenomena seperti ini sesungguhnya tidak mungkin ditangkap penelitian kuantitatif yang cenderung memaknai apa yang tampak (fisik), kasat mata dari jawaban yang diteliti.

Penelitian kualitatif mencoba lebih mendekat ke arah data, memaknai kata "iya" namun sesungguhnya keluar dengan keterpaksaan secara mendalam dan berulang, peneliti lebih jauh memahami kenapa jawaban itu muncul, kenapa harus informan berkata "iya" padahal sesungguhnya berarti "tidak" dan contohcontoh lain merupakan bentuk eksplorasi pendekatan kualitatif yang tidak ditemukan dalam metode kuantitatif. Dengan demikian, hampir semua Indera tubuh harus digunakan dalam penelitian kualitatif, yaitu penglihatan, pendengaran dan perasaan. Karena peneliti mencoba memaknai mendalam kata demi kata yang diucapkan informan, tidak hanya raut muka, bahasa tubuh yang menyertai ucapan itu juga menjadi perhatian penting dalam studi kualitatif.

Pertanyaan yang dipertanyakan pada studi kuantitatif apakah mungkin suara hati, perasaan terdalam yang mencerminkan kebenaran dari diri informan dapat keluar dengan hanya isi kuesioner, yang boleh jadi tidak sepenuhnya dimengerti oleh responden itu sendiri? Atau mewawancarai dengan cara terstruktur, tanpa lebih jauh mengenal dan memahami pribadi informan yang diwawancarai dan situasi perasaan informan pada saat wawancara berlangsung. Apalagi pertanyaan yang disusun peneliti sebenarnya tidak mewakili kondisi sebenarnya dalam diri responden atau informan karena terstruktur di atas meja, sehingga peluang untuk mengisi asalasalan sulit dihindari.

\section{PENUTUP}

Perbedaan antara penelitian kualitatif dan kuantitatif terletak pada hasil apa yang diharapkan peneliti dalam suatu fenomena dan lingkup penelitian yang dilakukan. Bila pertanyaannya adalah bagaimana hubungan (causalitas) antara dua fenomena atau lebih tentu cukup dilakukan dengan penelitian kuantitatif. Ruang lingkup penelitian relatif luas dan dapat menggeneralisir fenomena. Data yang dibutuhkan penelitian kuantitatif tentu data-data kuantitatif.

Sedangkan bila pertanyaannya mengapa suatu fenomena terjadi, bagaimana prosesnya, sehingga butuh jawaban detail dan perlu penelusuran mendalam maka digunakan penelitian kualitatif. Data yang digunakan adalah data-data kualitatif berupa pernyataan-pernyataan narasumber (informan). Kehadiran kualitatif tidak untuk menggenaralisir karena lingkup kajiannya hanya pada lokasi tertentu.

Dengan demikian, cakupan kuantitatif ibarat menggali gorong-gorong (got), luas, Panjang namun tidak dalam. Sedangkan penelitian kualitatif ibarat menggali sumur, diameter tidak luas namun sangat dalam. Atas dasar hal itu, kedua metode ini sangatlah penting dan saling melengkapi.

\section{REFERENSI}

Baden, S dan Major, C H. 2010. Wisdom And Uncertainty. Dalam Baden, Savin Dan Major, Claire Howell (Eds). New Approaches To Qualitative Research. Routledge: New York. 
Berg, B L, 2001. Qualitative Research Methods For The Social Sciences Fourth Edition. Allyn And Bacon: USA

Bryman, A, 2004. Quantity And Quality In Social Research. Routladge: London And New York.

Chamlee-Wright, E, 2010. Qualitative methods and the pursuit of economic understanding. Rev Austrian Econ (2010) 23:321-331.

Dobrovolny, J L dan Fuentes, S.C.G, 2008. Quantitative Versus Qualitative Evaluation: A Tool To Decide Which To Use. Performance Improvement, Vol. 47, No. 4, April 2008
Vainderstoep, S W dan Johanston, D D, 2009. Research Method Of Every Day Life: Blending Qualitative And Quantitative Approach. Sanfransisco: John Willey And Sons.

Sale, J E.M, Lohfeld, LH, Brazil, K, 2002. Revisiting the QuantitativeQualitative Debate: Implications forMixed-Methods Research. Quality \& Quantity 36: 43-53, 2002. 